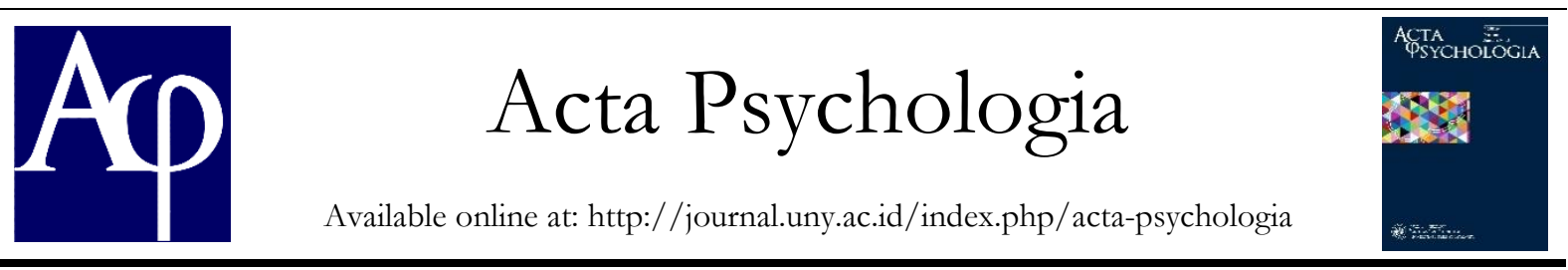

\title{
Hubungan Kecanduan Sosial Media dengan Kesepian pada Mahasiswa
}

\author{
Habibah Miftahurrahmah, Farida Harahap \\ Program Studi Psikologi, Universitas Negeri Yogyakarta; Jl. Colombo No. 1 Sleman Yogyakarta, \\ 55281 \\ habibah.miftahurrahmah2016@student.uny.ac.id
}

\begin{abstract}
Abstrak
Penggunaan sosial media dapat digolongkan sebagai kecanduan apabila sampai mengganggu kemampuan fungsional individu. Peningkatan kecanduan sosial media terkait dengan peningkatan kesepian. Penelitian ini bertujuan untuk mendeskripsikan hubungan antara kecanduan sosial media dengan kesepian pada mahasiswa. Pendekatan yang digunakan dalam penelitian ini adalah kuantitatif korelasional. Sampel dalam penelitian ini merupakan 110 mahasiswa Universitas Negeri Yogyakarta dan dilakukan dengan metode purposive sampling. Instrumen yang digunakan adalah alat ukur mengenai kecanduan sosial media dan kesepian yang telah melalui proses uji validitas dan reliabilitas. Instrumen tersebut kemudian disebar dengan metode kuesioner online dan diskor dengan menggunakan skala Likert. Analisis data dilakukan dengan Pearson product moment. Sebagian besar responden mengalami kecanduan sosial media dan kesepian pada taraf sedang. Terdapat hubungan signifikan antara kecanduan sosmed dengan kesepian $(\mathrm{p}=0,306)$. WhatsApp menjadi sosial media yang paling banyak digunakan oleh mahasiswa $(90 \%)$.

Kata Kunci: kecanduan sosial media, kesepian, mahasiswa
\end{abstract}

\begin{abstract}
Social media use could be classified as addiction if interfered with individual's functional abilities. Social media addiction's increase related with loneliness' increase. This research aimed to describe correlation between social media addiction and loneliness among college students. The approach used in this research was quantitative correlational. Sample used in this study were 110 Yogyakarta State University students and was carried out by purposive sampling method. The instruments used were social media addiction and loneliness scale which have been tested for the validity and reliability. The instruments were distributed by online questionnaire and scored using a Likert scale. Data analysis was performed by using Pearson product moment. Most of the respondents experienced moderate social media addiction and loneliness. There was a significant relationship between social media addiction and loneliness $(p=0.306)$. WhatsApp was the most used social media by students $(90 \%)$.
\end{abstract}

Keywords: social media addiction, loneliness, college student

\section{Pendahuluan}

Sosial media sudah menjadi bagian yang tak terpisahkan dari masyarakat modern ini. Survei menunjukkan total pengguna sosial media hingga awal tahun 2020 mencapai 3,8 miliar orang (Kemp, 2020) dan umumnya didominasi oleh individu berusia 18 hingga 29 tahun (Perrin \& Anderson, 2019). Indonesia menduduki peringkat ketiga negara dengan durasi penggunaan sosial media tertinggi di dunia, yakni selama 3 jam 26 menit per hari (Kemp, 2020). Hal ini menunjukkan bahwa penggunaan sosial media masyarakat di Indonesia jauh di atas rata-rata penggunaan sosial media secara global, yakni selama 2 jam 24 menit atau sekitar 144 menit per harinya.

Meningkatnya penggunaan sosial media berarti jumlah waktu yang digunakan untuk menggunakan sosial media juga akan bertambah. Perilaku mengecek sosial media secara berulang ini didasari oleh fear of 
missing out (FoMO), yaitu kekhawatiran apabila melewatkan suatu informasi atau hal yang dibagikan oleh orang lain (Dhir, et al, 2018: 143). Individu menjadi terikat dengan ponsel untuk menghindari perasaan terasing dari orang lain dan agar tidak tertinggal hal-hal terbaru di sosial media. Tak jarang, individu menemukan pembaruan yang tidak dikehendaki dan memicu perasaan terisolasi. Sebagai contoh, apabila seseorang melihat temannya membagikan foto sedang mengadakan acara atau berkumpul dan tidak mengajak orang tersebut maka akan timbul perasaan dikucilkan. Perasan terisolasi dan dikucilkan inilah yang umum disebut sebagai kesepian.

Dari penjabaran tersebut, penelitian ini bertujuan untuk mengetahui hubungan antara kecanduan sosial media dengan kesepian yang dialami mahasiswa. Manfaat yang dapat diperoleh dari penelitian ini adalah sebagai sumber informasi tentang kecanduan sosial media dan kesepian serta sebagai dasar melakukan intervensi pada masalah perilaku, terutama kecanduan sosial media.

Kecanduan sosial media didefinisikan sebagai ketergantungan seseorang terhadap sosial media dan munculnya perasaan tidak menyenangkan apabila tidak bisa menggunakan sosial media tersebut (Longstreet \& Brooks, 2017: 74). Kecanduan ini merupakan bagian dari kecanduan internet. Aspekaspek yang meliputi terdiri dari gejala penarikan, kehilangan kendali, preokupasi, konflik, dan coping (Meerkerk, et al, 2009: 2). Sementara faktor yang mempengaruhi kecanduan sosial media yakni konten, ketersediaan dan akses, penghargaan, sosial, dan generasi digital (Greenfield, 2010: 140).

Kesepian merupakan pengalaman tak menyenangkan yang bersifat subjektif dan dialami seseorang ketika harapan mereka mengenai suatu hubungan interpersonal tidak sebanding dengan apa yang keyataannya dialami (Perlman, 2019:
1). Aspek yang terdapat pada kesepian meliputi sosial dan emosional (Perlman \& Peplau, 1984: 17). Faktor yang mempengaruhi kesepian diantaranya adalah ketidakmampuan personal, permasalahan di masa perkembangan, tidak terpenuhinya kebutuhan akan hubungan akrab, pindah ke tempat baru atau perpisahan, dan marginalitas sosial (Rokach, 2019: 124).

Terdapat beberapa ahli di luar negeri yang meneliti keterkaitan antara kecanduan sosial media dengan kesepian. Terdapat korelasi antara penggunaan Facebook dengan kesepian. Rasa malu dan dukungan sosial yang rendah memprediksi munculnya kesepian yang mendorong penggunaan Facebook sebagai kompensasi atas kemampuan sosial mereka yang kurang (Song, et al., 2014: 450). Kesepian akan meningkat sejalan dengan penggunaan sosial media. Individu yang kurang memiliki kontrol terhadap impulsnya akan cenderung menggunakan sosial media secara berlebihan (Savci \& Aysan, 2016: 112). Pada individu yang menggunakan sosial media selama lebih dari 120 menit per hari, mereka mengalami isolasi sosial dua kali lebih besar dibanding individu yang menggunakan sosial media selama kurang dari 60 menit per harinya (Primack, 2017: 5). Penelitian lain menunjukkan bahwa pada individu yang mengalami kesepian, motivasi menggunakan sosial media seperti Facebook akan meningkat untuk memenuhi kebutuhan interaksinya (Guo, 2018: 57). Untuk penelitian yang dilakukan di Indonesia, baru meneliti hubungan antara kecanduan internet dengan kesepian pada mahasiswa (Oktapiani, 2019: 7). Hasilnya, sebagian besar subjek mengalami kecanduan internet dan kesepian pada taraf sedang. Kesepian memiliki pengaruh sebesar 21,1\% pada kecanduan internet, sementara selebihnya dipengaruhi oleh faktor lain.

Dari beberapa riset terdahulu yang telah dilakukan, penelitian ini mencoba mendeskripsikan korelasi antara kecanduan sosial media dan kesepian pada kelompok 
mahasiswa serta mendeskripsikan tingkat kecanduan dan kesepian berdasarkan aspek-aspeknya. Untuk kerangka berpikir penelitian ini dapat dilihat sebagai berikut.

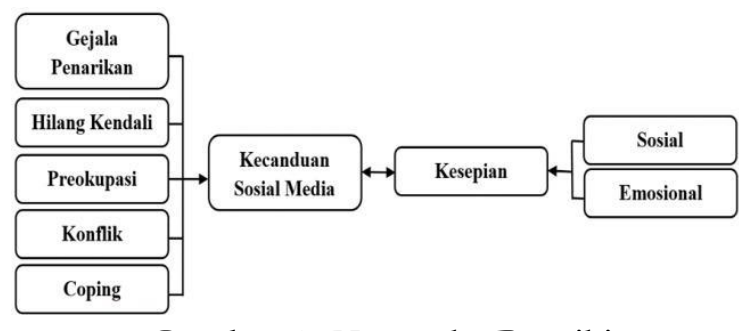

Gambar 1. Kerangka Berpikir

Hipotesis $(\mathrm{Ha})$ yang dijukan pada penelitian ini adalah ada korelasi positif antara kecanduan sosial media dengan kesepian.

\section{Metode Penelitian}

Penelitian ini menggunakan pendekatan kuantitatif korelasi, karena penelitian ini berfokus pada hubungan dari kedua variabel tersebut.

Penelitian ini dilaksanakan di Kota Yogyakarta, Daerah Istimewa Yogyakarta. Waktu penelitian ini dimulai pada bulan Juli hingga Agustus tahun 2020.

Populasi dalam penelitian ini adalah individu dewasa awal yang berusia antara 18 hingga 25 tahun. Teknik pengambilan sampel yang digunakan merupakan purposive sampling, yaitu berdasarkan tujuan yang telah ditetapkan sebelumnya. Kriteria sampel dalam penelitian ini adalah mahasiswa Universitas Negeri Yogyakarta yang berusia antara 18 hingga 25 tahun dan memiliki setidaknya satu akun sosial media yang aktif digunakan.

Data, Instrumen, dan Teknik Pengumpulan Data

Teknik pengumpulan data yang digunakan adalah dengan menggunakan skala Likert pada masing-masing instrumen. Pengukuran kecanduan sosial media menggunakan lima pilihan jawaban dengan rentang skor 1 (tidak pernah) hingga 5 (selalu). Terdapat beberapa butir dalam skala kesepian yang bersifat unfavorable, sehingga untuk penilaiannya dibalik dengan rentang skor 1 (selalu) hingga 5 (tidak pernah).

Data yang diperoleh dari penelitian ini tergolong dalam data ordinal. Instrumen yang digunakan merupakan hasil modifikasi dari instrumen compulsive internet use scale (Meerkerk, et al, 2009: 3) serta Revised UCLA Loneliness Scale (Russell, Peplau, \& Cutrona, 1980: 475). Data diperoleh dari responden melalui instrumen kecanduan sosial media dan kesepian yang disebar secara online.

Penelitian ini menggunakan analisis deskriptif untuk memberikan gambaran mengenai data dari variabel yang didapatkan dari kelompok subjek penelitian (Azwar, 2018). Data yang diperoleh masih berupa data ordinal, maka harus diubah ke data interval agar memudahkan untuk disajikan dalam beberapa kategori.

Uji prasyarat analisis diperlukan sebelum ke tahap analisis data untuk menguji hipotesis. Uji ini meliputi:

1. Uji normalitas. Dilakukan untuk mengetahui distribusi data yang diperoleh. Dalam penelitian ini, uji normalitas dilakukan dengan bantuan program SPSS 25 menggunakan Formula Kolmogorov-Smirnov.

2. Uji linearitas data. Dilakukan untuk memastikan bahwa kedua variabel memiliki hubungan yang searah. Dalam penelitian ini, uji linearitas dara dilakukan dengan menggunakan SPSS 25 dengan kriteria apabila kedua variabel memiliki nilai $>0,05$ maka dapat dikatakan linear.

Untuk melakukan uji hipotesis, penelitian ini menggunakan persamaan korelasi product moment dari Pearson dengan bantuan program SPSS 25 . Kekuatan hubungan kedua variabel dinyatakan oleh besaran angka 0 hingga 1 dan arah hubungan yang dinyatakan dalam tanda positif maupun negatif (Azwar, 2018: 
205). Koefisien korelasi yang bersifat positif mengindikasikan hubungan searah antara kedua variabel, sementara korelasi yang sifatnya negatif menandakan bahwa hubungan yang berlawanan arah.

\section{Hasil Penelitian dan Pembahasan}

Responden dalam penelitian ini merupakan mahasiswa Universitas Negeri Yogyakarta yang berusia antara 18 hingga 25 tahun sebanyak 110 orang. Mayoritas responden adalah wanita $(75,5 \%)$. Untuk lebih jelasnya dapat dilihat pada tabel-tabel berikut.

Tabel 1. Persebaran Usia Responden

\begin{tabular}{lll}
\hline Usia & Jumlah & Persentase \\
\hline 18 & 6 & $5,5 \%$ \\
19 & 6 & $5,5 \%$ \\
20 & 20 & $18,2 \%$ \\
21 & 42 & $38,2 \%$ \\
22 & 22 & $20 \%$ \\
23 & 8 & $7,3 \%$ \\
24 & 3 & $2,7 \%$ \\
25 & 3 & $2,7 \%$ \\
\hline Total & 110 & $100 \%$ \\
\hline
\end{tabular}

Dari tabel tersebut, dapat diketahui bahwa sebagian besar responden berusia 21 tahun $(38,2 \%)$, diikuti kelompok usia 22 tahun $(20 \%)$ dan 20 tahun (18,2\%). Ratarata usia responden adalah 21,08.

Tabel 2. Durasi Penggunaan Sosmed per Hari

\begin{tabular}{lll}
\hline Durasi & Jumlah & Persentase \\
\hline Kurang dari 1 jam & 1 & $0,9 \%$ \\
1 hingga 2 jam & 5 & $4,5 \%$ \\
2 hingga 3 jam & 19 & $17,3 \%$ \\
Lebih dari 3 jam & 85 & $77,3 \%$ \\
\hline Total & 110 & $100 \%$ \\
\hline
\end{tabular}

Dari tabel tersebut, dapat diperoleh informasi bahwa mayoritas responden menggunakan sosial media selama lebih dari 3 jam dalam sehari $(77,3 \%)$. Selebihnya, responden menggunakan sosmed kurang dari 3 jam setiap harinya.

Tabel 3. Jenis Sosmed yang Digunakan

\begin{tabular}{lll}
\hline Jenis Sosmed & Jumlah & Persentase \\
\hline WhatsApp & 99 & $90 \%$ \\
Instagram & 89 & $80,9 \%$ \\
YouTube & 78 & $70,9 \%$ \\
Twitter & 65 & $59,1 \%$ \\
Line & 34 & $30,9 \%$ \\
Facebook & 24 & $21,8 \%$ \\
\hline
\end{tabular}

Dari tabel tersebut diketahui bahwa WhatsApp menjad sosial media yang paling banyak digunakan (90\%), kemudian diikuti Instagram (80,9\%), YouTube (70,9\%), Twitter (59,1\%), Line $(30,9 \%)$, dan terakhir Facebook $(21,8 \%)$.

Kategorisasi Variabel

Untuk kategorisasi tingkat kecanduan sosial media dan kesepian dikelompokkan berdasar aspek-aspeknya. Lebih jelasnya dapat dilihat pada grafikgrafik berikut.

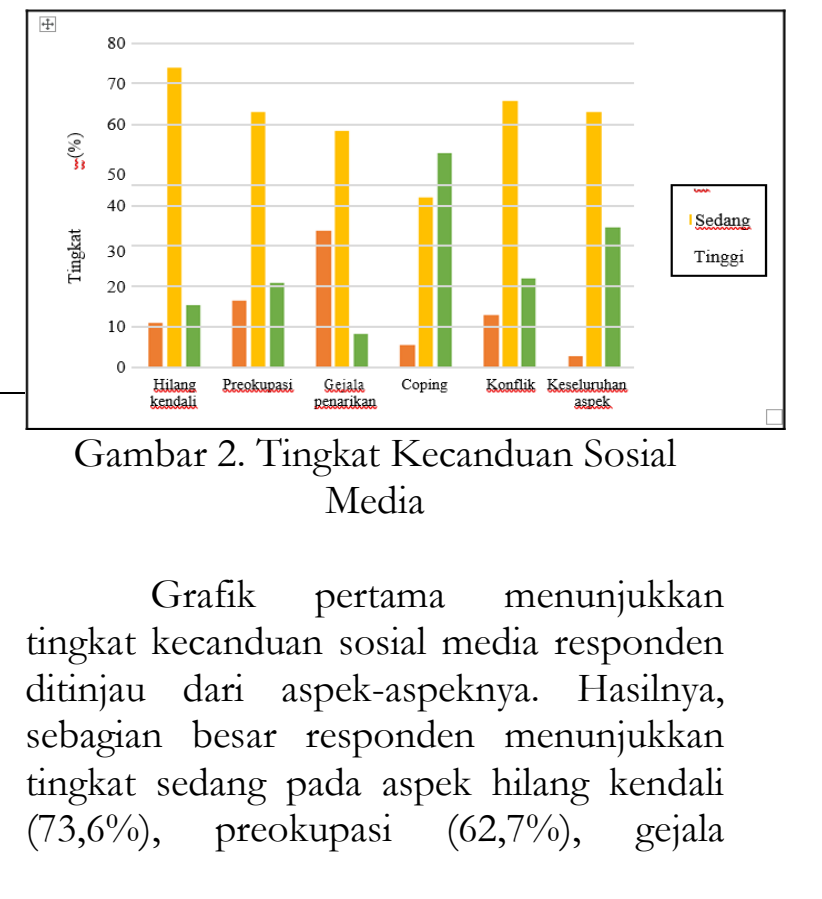


penarikan (58,2\%), dan konflik (65,5\%). Pada aspek coping, mayoritas responden berada pada taraf tinggi (52,7\%). Apabila ditinjau secara keseluruhan dengan menggabungkan kelima aspek tersebut, sebagian besar responden mengalami kecanduan di tingkat sedang $(62,7 \%)$.

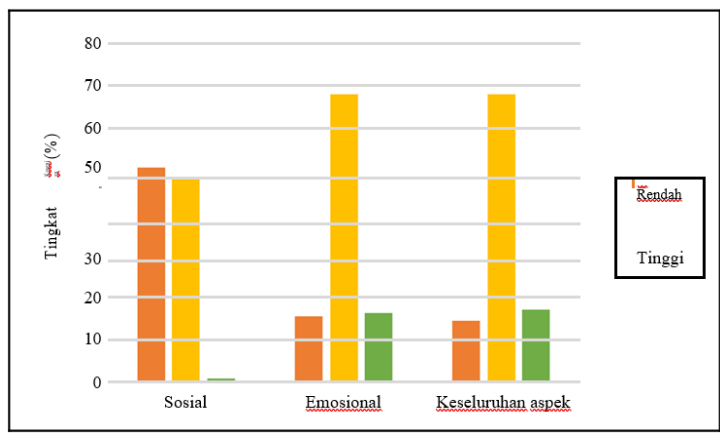

Gambar 3. Tingkat Kesepian

Grafik berikutnya menunjukkan tingkat kesepian ditinjau dari aspekaspeknya. Hasilnya, sebagian besar responden berada di taraf rendah pada aspek sosial $(50,9 \%)$. sementara pada aspek emosional sebagian besar responden berada di taraf sedang $(68,2 \%)$. Apabila ditinjau secara keseluruhan dengan menggabungkan kedua aspek tersebut, maka diperoleh temuan bahwa sebagian besar responden mengalami kesepian pada taraf sedang $(68,2 \%)$.

\section{Uji Prasyarat Analisis}

Uji normalitas yang dilakukan pada data yang telah diperoleh menunjukkan nilai signifikansi sebesar 0,002 (sig < 0,05). Hal ini menandakan bahwa distribusi data tergolong tidak Kurva pada analisis uji residu menunjukkan puncak dari kurva tersebut condong ke arah kiri.

Uji linearitas yang dilakukan pada data yang telah diperoleh menunjukkan nilai 0,389 (sig 0,05). Maka, dapat disimpulkan bahwa kedua variabel tersebut memiliki hubungan yang linear, sehingga dapat dilakukan uji korelasi
Uji Hipotesis

Hipotesis pada penelitian ini adalah ada korelasi positif antara kecanduan sosial media dengan kesepian. Untuk menjawab hipotesis tersebut, maka dilakukan analisis korelasi Product Moment Pearson dengan bantuan program SPSS 25. Hasilnya dapat dilihat pada tabel berikut.

Tabel 4. Korelasi Product Moment Pearson

\begin{tabular}{|c|c|c|c|}
\hline & & $\frac{\text { Kecanduan }}{\text { Sosial Media }}$ & Kesepian \\
\hline \multirow[t]{3}{*}{$\begin{array}{l}\text { Kecanduan } \\
\text { Sosial Media }\end{array}$} & $\begin{array}{l}\text { Pearson } \\
\text { Correlation }\end{array}$ & 1 &, 306 \\
\hline & $\begin{array}{l}\text { Sig. (2- } \\
\text { tailed) }\end{array}$ & & 0,001 \\
\hline & $\mathrm{N}$ & 110 & 110 \\
\hline \multirow[t]{3}{*}{ Kesepian } & $\begin{array}{l}\text { Pearson } \\
\text { Correlation }\end{array}$ & $306^{\prime \prime}$ & 1 \\
\hline & $\begin{array}{l}\text { Sig. (2- } \\
\text { tailed) }\end{array}$ & 0,001 & \\
\hline & $\mathrm{N}$ & 110 & 110 \\
\hline
\end{tabular}

Berdasarkan tabel tersebut, diperoleh nilai korelasi (p) sebesar 0,306 dengan nilai signifikansi (Sig. 2-tailed) sebesar 0,001. Dapat disimpulkan bahwa terdapat korelasi yang signifikan antara kedua variabel dan bernilai positif, yakni apabila kecanduan sosial media meningkat maka kesepian juga akan mengalami kenaikan dan berlaku pula sebaliknya. Hubungan antara kedua variabel yang bernilai 0,306 menunjukkan bahwa tingkat korelasinya berada di taraf rendah.

Berdasarkan deskripsi hasil penelitian, dapat dikatakan bahwa terdapat korelasi yang signifikan antara kecanduan sosial media dengan kesepian pada mahasiswa dalam taraf yang rendah. Hubungan antara kecanduan sosial media dengan kesepian bernilai positif, yang artinya semakin tinggi tingkat kecanduan sosial media seseorang maka kesepian juga akan meningkat. Hal yang sama juga berlaku apabila kesepian meningkat maka kecanduan sosial media juga mengalami kenaikan. Nilai korelasi sebesar 0,306 artinya tingkat korelasi dari kecanduan 
sosial media dengan kesepian tergolong rendah.

Penelitian mengenai kecanduan sosial media dan kesepian ini memiliki korelasi yang rendah dikarenakan adanya beberapa hal. Data mengenai tingkat kecanduan sosial media maupun kesepian pada mahasiswa keduanya berada pada kategori sedang. Ini menunjukkan bahwa mahasiswa tidak mengalami kecanduan sosial media maupun kesepian dalam taraf yang cukup serius, sehingga korelasi antara kedua variabel tersebut tergolong rendah.

Hasil analisis deskriptif mengenai kecanduan sosial media menunjukkan bahwa sebagian besar responden berada dalam kategori sedang (62,7\%). Meskipun mayoritas berada di taraf sedang, perlu diperhatikan bahwa terdapat beberapa responden yang mengalami kecanduan sosial media di taraf tinggi $(34,5 \%)$. Hal ini perlu menjadi perhatian karena ternyata penggunaan sosial media pada mahasiswa telah mencapai tingkat kecanduan. Baik responden yang mengalami kecanduan di taraf sedang maupun tinggi memiliki resiko sebagai akibat dari penggunaan sosial media yang berlebihan.

Apabila ditinjau dari aspek-aspek kecanduan sosial media, sebagian besar responden berada pada taraf sedang pada aspek hilang kendali $(73,6 \%)$, preokupasi $(62,7 \%)$, gejala penarikan $(58,2 \%)$, dan konflik $(65,5 \%)$. Sementara pada aspek coping mayoritas responden berada pada kategori yang tinggi $(52,7 \%)$.

Pada aspek hilang kendali, sebagian responden tidak dapat mengontrol penggunaan sosial media dan merasakan dorongan untuk terus menggunakan sosial media. Pada aspek preokupasi, sebagian responden lebih memilih untuk menggunakan sosial media dibanding kegiatan lainnya dan memikirkan sosial media mereka. Pada aspek gejala penarikan, responden merasakan perasaan tak nyaman dan berbagai emosi negatif ketika tidak bisa menggunakan sosial medianya. Pada aspek konflik, sebagian responden mengabaikan kewajiban dan orang lain karena menggunakan sosial media. Terakhir, pada aspek coping sebagian besar responden menggunakan sosial media sebagai cara mengatasi masalah dan untuk menghibur diri. Penggunaan sosial media sebagai bentuk mengatasi masalah yang dialami sejalan dengan hasil penelitian terdahulu (Song, et al, 2014: 450; Guo, 2018: 57). Hal ini menunjukkan bahwa meskipun penggunaan sosial media yang dilakukan mahasiswa sebagian besar tergolong dalam kategori yang wajar, mereka juga tetap mengalami resiko apabila perilaku tersebut terus berulang dan menimbulkan permasalahan lain.

Perilaku penggunaan sosial media ini disebabkan oleh beberapa hal berdasarkan teori mengenai kecanduan sosial media. Faktor pertama yaitu konten yang ada di dalam sosial media (Greenfield, 2010: 140). Konten sangat berpengaruh pada minat dan ketertarikan seseorang untuk mengakses sosial media, umumnya orang akan menggunakan sosial media lebih lama ketika menemukan konten yang menarik dan menghibur. Sebaliknya, ketika menemukan konten yang tidak dikehendaki maka pengguna sosial media akan merasa kesal dan tidak senang. Sebagai contoh, apabila individu melihat temannya membagikan foto sedang mengadakan acara atau berkumpul dan tidak mengajak orang tersebut maka akan timbul perasaan dikucilkan.

Faktor kedua yaitu faktor sosial (Greenfield, 2010: 146). Fungsi dari sosial media selain untuk menghubungkan antar individu adalah membangun isolasi sosial. Meskipun kedua fungsi tersebut bertolak belakang, namun tak dapat dipungkiri bahwa banyak orang yang merasa terhubung dengan mereka yang jauh dan merasa terpisah dari orang-orang yang dekat secara fisik ketika menggunakan sosial media. Faktor utama dari munculnya gangguan kecanduan sosial media adalah keinginan alami manusia untuk terhubung secara sosial. Ketika tidak dapat bertemu 
secara langsung, keberadaan sosial media sanggup memenuhi kebutuhan untuk terhubung dengan orang lain. Penggunaan sosial media dapat dikategorikan sebagai kecanduan apabila sampai mengganggu relasi dengan orang lain, penurunan kemampuan fungsional, dan konsekuensi negatif lainnya.

Hasil analisis deskriptif mengenai kesepian menunjukkan bahwa sebagian besar responden mengalami kesepian pada kategori sedang (68,2\%). Ditinjau dari aspek-aspeknya, pada aspek emosional sebagian besar responden megalami kesepian pada taraf rendah $(50,9 \%)$ dan pada aspek sosial menunjukkan taraf sedang $(68,2 \%)$. Pada aspek pertama yaitu emosional, meskipun didominasi responden dengan tingkat kesepian rendah yakni $50,9 \%$, jumlah responden yang mengalami kesepian pada taraf sedang sebesar 48,2\% menunjukkan bahwa kesepian emosional dapat membuat para responden mengalami emosi negatif dan menilai bahwa mereka tidak menyenangkan. Pada aspek sosial, sebagian besar responden menyatakan bahwa tidak ada orang yang dekat dengan mereka dan merasa tidak cocok dengan orang lain.

Salah satu faktor yang berperan dalam munculnya rasa kesepian dalam penelitian ini dapat dijabarkan berdasarkan teori kesepian (Rokach, 2019: 123). Faktor tersebut yakni tidak terpenuhinya kebutuhan akan hubungan akrab. Kesepian muncul sebagai akibat dari kurangnya kontak sosial. Ketika seseorang tidak dapat menjalin relasi secara langsung dengan orang lain, mereka akan mencari cara lain untuk menemukan suatu hubungan pertemanan. Sosial media menjadi salah satu cara yang digunakan oleh orang-orang untuk memenuhi kebutuhan sosialnya secara virtual. Meskipun mereka telah menjalin kedekatan atau intimasi dengan teman di dunia maya, kualitas hubungan yang terjalin di sosial media lebih rendah dibanding hubungan yang terjalin secara langsung. Hal inilah yang menyebabkan perasaan kesepian yang terus ada meskipun sudah menjalin komunikasi dengan orang lain melalui sosial media.

Jenis sosial media yang paling sering digunakan oleh mahasiswa adalah WhatsApp (90\%). Temuan dari penelitian lain menunjukkan bahwa WhatsApp dinilai lebih memudahkan penggunanya untuk menjalin komunikasi yang lebih intens dan intim, sementara Facebook lebih sering digunakan untuk mencari informasi (Karapanos, Teixeira, \& Gouveia, 2016: 895).

\section{Simpulan dan Saran}

Berdasarkan pembahasan tersebut, maka dapat ditarik kesimpulan bahwa terdapat hubungan yang signifikan antara kecanduan sosial media dan kesepian pada mahasiswa Universitas Negeri Yogyakarta. Korelasi kedua variabel tersebut bertanda positif, yang menunjukkan hubungan yang searah. Apabila kecanduan sosial media meningkat maka kesepian juga akan mengalami kenaikan, berlaku juga sebaliknya.

Saran bagi masyarakat, diharapkan mampu memperhatikan penggunaan sosial media agar tidak berlebihan dan sampai mengalami kecanduan sosial media. Masyarakat dapat memahami bahwa kesepian juga dipicu dari penggunaan sosial media yang meningkat, sehingga perlu menumbuhkan kesadaran dan regulasi diri terhadap penggunaan sosial media.

\section{Daftar Pustaka}

Azwar, S. (2018). Metode Penelitian Psikologi (edisi 2). Yogyakarta: Pustaka Pelajar.

Dhir, A., Yossatorn, Y., Kaur, P., et al. (2018). Online social media fatigue and psychological wellbeing-A study of compulsive use, fear of missing out, fatigue, anxiety and depression. International Journal of Information Management, 40 (13), 141152. 
Greenfield, D. (2010). The Addictive Properties of Internet Usage. Dalam K. S. Young, \& C. N. Abreu, Internet Addiction: A Handbook and Guide to Evaluation and Treatment. New Jersey: John Wiley \& Sons, Inc

Guo, H. (2018). Linking Loneliness and Use of Social Media. Tesis Master, tidak diterbitkan, University of Helsinki, Helsinki, Finland.

Karapanos, E., Teixeira, P., \& Gouveia, R. (2016). Need fulfillment and experiences on social media: A case on Facebook and WhatsApp. Computers in Human Behavior, 55 (30), 888-897

Kemp, S. (2020). Digital 2020: 3.8 Billion People Use Social Media. Diakses pada 8 September $2020 \quad$ dari www.wearesocial.com

Longstreet, P., \& Brooks, S. (2017). Life satisfaction: A key to managing internet \& social media addiction. Technology in Society, 50 (9), 73-77.

Meerkerk, G. J., van den Eijnden, R. J., Vermulst, A. A., et al. (2009). The Compulsive Internet Use Scale (CIUS): Some Psychometric Properties. Cyber Psychology \& Behavior, 12(1), 1-6/

Oktapiani, R. W. (2019). Hubungan antara Kesepian dengan Kecanduan Internet pada Mahasiswa. Skripsi. Diakses dari UMBY Repository: eprints.mercubuana-yogya.ac.id

Perlman, D. (2019). Loneliness: A life-span, family perspective. Diakses pada 8 September 2020 dari www.researchgate.net

Perlman, D., \& Peplau, L. A. (1984). Loneliness Research: A Survey of Empirical Findings. Dalam L. A. Peplau, \& S. E. Goldston (Eds.)
Preventing the Harmful Consequences of Severe and Persistent Loneliness. Maryland: National Institute of Mental Health.

Perrin, A., \& Anderson, M. (2019). Share of U.S. adults using social media, including Facebook, is mostly unchanged since 2018. Diakses pada 8 September 2020 dari www.pewinternet.org

Primack, B. A., Shensa, A., Sidani, J. E., et al. (2017). Social Media Use and Perceived Social Isolation among Young Adults in the US. American Journal of Preventive Medicine, 53(1), 1-8.

Rokach, A. (2019). The Psychological Journey To and From Loneliness: Development, Causes, and Effects of Social and Emotional Isolation (1st ed.). San Diego: Elsevier Science Publishing.

Russell, D., Peplau, L. A., \& Cutrona, C. E. (1980). The Revised UCLA Loneliness Scale: Concurrent and Discriminant Validity Evidence. Journal of Personality and Social Psychology, 39 (3), 472-480

Savci, M., \& Aysan, F. (2016). Relationship between Impulsivity, Social Media Usage and Loneliness. Educational Process: International Journal, 5 (2), 106115.

Song, H., Zmyslinski-Seelig, A., Kim, J., et al. (2014). Does Facebook make you lonely?: A meta analysis. Computers in Human Behavior, 36 (48), 446-452. 